\title{
Менеджмент персоналу
}

\section{РЕГУЛЮВАННЯ РЕГІОНАЛЬНОГО РИНКУ ПРАЦІ НА ОСНОВІ ВИКОРИСТАННЯ МЕТОДІВ НАВЧАННЯ НАСЕЛЕННЯ ПРОТЯГОМ УСЬОГО ЖИТТЯ}

Постановка проблеми. Функціонування регіонального ринку праці є досить складним процесом, який вимагає залучення цілісного комплексу ресурсів, потенційних можливостей, методів, інструментів й управлінських дій, спрямованих на неперервну активізацію використання наявних і стимулювання створення та/або привласнення новітніх інноваційних знань економічно активного населення. Виникає необхідність створення найбільш сприятливих умов для повного розкриття талантів кожної людини саме на тій території, де вона народилася або тривалий час проживає, що буде супроводжуватися поступовим скороченням міграційних потоків мобільної частини населення у бік більш економічно розвинених регіонів країни та світу. Отже, для втілення зазначених цілей необхідно докорінним чином змінити вектори політики регіонального розвитку та активізації функціонування регіонального ринку праці, зорієнтував їх на розробку дієвих заходів у напрямі підвищення ефективності функціонування ринку праці за рахунок впровадження стратегій навчання протягом життя населення регіону.

Аналіз досліджень. Досвід розвинених країн світу свідчить про високу результативність партнерської взаємодії виробничо-комерційного, освітнього та наукового секторів економіки регіону, у результаті чого ринок праці насичується висококваліфікованими кадрами й інноваційною конкурентоспроможною продукцією та послугами, в основу створення яких було покладено прогресивні знання, впровадження нововведень у всі складові виробничо-господарської діяльності, активне залучення талановитої молоді та неперервний процес професійного розвитку дорослої людини $[1 ; 2 ; 3 ; 4$, с. 66; 5, с. 5]. У цих процесах досить вагому роль відіграють ті підходи та методи, що спрямовані на активізацію творчої та розумової діяльності людини, поступове виховання особистості у дусі відповідального громадянина та висококласного фахівця, психологічно налаштованого та професійного здатного до впровадження докорінних змін.

У дослідженні Д. Гаврилова і Е. Бардасової розкрито особливості інноваційних технологій, які можна використовувати в кадровому менеджменті і які сприяють розвитку якісних характеристик пропозиції робочої сили на ринку праці [1]. У працях Г. Іцковиц, 3. Гельмінової, А. Бутрина, Н. Гарта розкривається сутність функціонування підприємницького університету, який дозволяє диверсифікувати знання молодих фахівців, що робить їх конкурентоспроможними на ринку праці [2; 3]. В. Шовкалюк визначає умови створення кластерів та розкриває їхній вплив на розумовий розвиток населення [5]. Попри великої кількості публікацій, що присвячено регулюванню ринку праці, недостатньо розкрито різноаспектні методи навчання економічно активного населення протягом усього життя, що $є$ основою для оптимізації якісних характеристик попиту і пропозиції робочої сили.

Тому метою статті $\epsilon$ визначення методів нагромадження знань людиною протягом іiі життя та інструментів кадрового менеджменту суб'єктами господарювання для забезпечення розвитку регіонального ринку праці.

Виклад основного матеріалу дослідження. Виходячи $з$ того, що основним виробником, носієм і користувачем знань виступає людина, саме на ії̈ потреби та потенційні можливості доцільно орієнтуватися під час обгрунтування комплексної системи управління знаннями на рівні регіону, яка має бути покладеною в основу стратегії розвитку ринку праці на регіональному рівні. При цьому обов'язковою умовою має стати охоплення відповідними заходами людей усіх вікових категорій - від народження і до останніх хвилин життя. Слід також зазначити, що результативність тих чи інших заходів буде варіюватися залежно від того віку, в якому знаходиться людина, оскільки для певної вікової категорії мають застосовуватися окремі інструменти управління знаннями у межах системи інструментарію регіонального менеджменту. 3 цією метою доцільно більш чітко виокремити стадії життєвого циклу людини.

Дослідження й узагальнення підходів, що використовуються у науковому середовищі до розмежування стадій життєвого циклу людини дозволило обрати п’ять загальноприйнятих етапів, кожен 3 яких $є$ чітко регламентованим за віковими критеріями: 
дитинство - перший період життєвого циклу людини, який починається від народження, триває у середньому до десяти років і визначається часом людського розвитку, пов'язаного зі сприйняттям навколишнього середовища;

юність - період життєвого циклу людини, який у середньому триває 3 одинадцяти до двадцяти трьох років і пов'язаний з навчанням, професійним самовизначенням, отриманням відповідного фаху, пошуком роботи;

зрілість - період життєвого циклу людини, який у середньому триває 3 двадцяти чотирьох до тридцяти дев'яти років і пов'язаний 3 побудовою власної родини, кар'єрним зростанням й орієнтований на максимальне накопичення матеріальних благ, рівнів і ступенів кваліфікації;

мудрість - період життєвого циклу людини, який у середньому триває 3 сорока до п’ятдесяти дев’яти років і пов'язаний з максимізацією усвідомлення професійного досвіду, знань і навичок, їх використання на практиці та прагнення до передачі молодому поколінню фахівців;

зріла досвідченість - період життєвого циклу людини, який у середньому триває з шістдесяти років і до кінця життя і пов’язаний з переключенням уваги з професійної кар'єри на особистісне життя та родину [6, с. 32-34; 7].

На кожному з п'яти виокремлених етапів життєвого циклу людини відбуваються різні за напрямом, інтенсивністю та змістовною наповненістю процеси привласнення, генерації та практичного застосування знань, саме тому на рівні регіону мають бути використаними певні інструменти їхньої активізації, що буде сприяти нагромадженню інтелектуального, людського й інноваційного капіталів та пришвидшенню знаннєвого розвитку (табл. 1).

Таблиия 1

\section{Систематизація інструментів знаннсвого розвитку людини} протягом їі життя та їхнс змістовне наповнення

\begin{tabular}{|c|c|c|}
\hline $\begin{array}{l}\text { Стадія жит- } \\
\text { тєвого циклу } \\
\text { людини }\end{array}$ & Інструмент & $\begin{array}{c}\text { Змістовне наповнення } \\
\text { щодо застосування інструменту }\end{array}$ \\
\hline \multirow{2}{*}{ 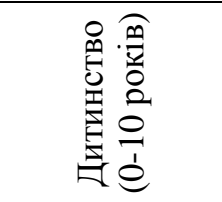 } & $\begin{array}{l}\text { «Емоційний компас», } \\
\text { ТРВ3, мнемоніка, } \\
\text { ментальна арифметика }\end{array}$ & $\begin{array}{l}\text { Цілеспрямований емоційний й інтелектуальний розвиток } \\
\text { особистості, прояв талантів і здатностей до чогось як ос- } \\
\text { нови подальшого життєвого успіху }\end{array}$ \\
\hline & $\begin{array}{l}\text { STEM-освіта, } \\
\text { STEM-проєкти }\end{array}$ & $\begin{array}{l}\text { Популяризація науки та наукових досягнень для дітей різ- } \\
\text { ного віку в ігровій та інтерактивній формах }\end{array}$ \\
\hline \multirow{7}{*}{ 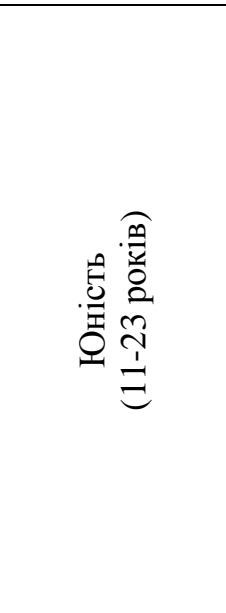 } & $\begin{array}{l}\text { Наукові олімпіади, } \\
\text { конкурси, турніри }\end{array}$ & $\begin{array}{l}\text { Відбір найбільш талановитих і всебічний їх розвиток, спря- } \\
\text { мована фінансова підтримка владою регіону }\end{array}$ \\
\hline & Наукові пікніки у ЗВО & Профорієнтація молоді на суспільно значущі позиції \\
\hline & Івент-платформи & $\begin{array}{l}\text { Проведення спеціалізованих семінарів і тренінгів у присто- } \\
\text { сованих для цього локаціях, спрямованих на інтелектуаль- } \\
\text { ний, фізичний і творчий розвиток учасників }\end{array}$ \\
\hline & $\begin{array}{c}\text { Автоматизовані } \\
\text { платформи бізнес-освіти }\end{array}$ & $\begin{array}{l}\text { Відкритий доступ до програм дистанційного навчання та } \\
\text { досліджень за обраною тематикою }\end{array}$ \\
\hline & $\begin{array}{l}\text { Освітньо-наукові клас- } \\
\text { тери, бізнес-інкубатори }\end{array}$ & $\begin{array}{l}\text { Узгодження вимог роботодавців до робочої сили та можли- } \\
\text { востей навчальних закладів щодо їі якісної підготовки, на- } \\
\text { буття професійного досвіду молоддю }\end{array}$ \\
\hline & Портфоліо студента & Спрямований пошук роботи за фахом під час навчання \\
\hline & $\begin{array}{l}\text { Орієнтація на дефіцитні } \\
\text { та унікальні професії } \\
\text { (траблшутер тощо) }\end{array}$ & $\begin{array}{l}\text { Вибір професії або спеціальності, що гарантовано дозво- } \\
\text { лить працевлаштуватися, отримати високий рівень оплати } \\
\text { праці та гідні їі умови }\end{array}$ \\
\hline \multirow{3}{*}{ 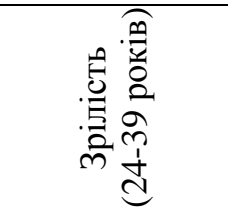 } & $\begin{array}{l}\text { Інструменти кадрового } \\
\text { менеджменту }\end{array}$ & $\begin{array}{l}\text { Управлінські процедури внутрішнього й зовнішнього ха- } \\
\text { рактеру, пов’язані з процесами трансформації знань }\end{array}$ \\
\hline & Дизайн-мислення & $\begin{array}{l}\text { Методологія пошуку рішень в умовах невизначеності, за- } \\
\text { снованого на творчому й аналітичному мисленні }\end{array}$ \\
\hline & Коворкінг & Гнучка організація робочого процесу групи людей \\
\hline \multirow{2}{*}{ 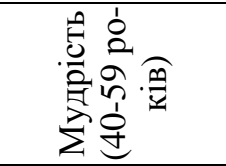 } & $\begin{array}{l}\text { Інструменти кадрового } \\
\text { менеджменту }\end{array}$ & $\begin{array}{l}\text { Управлінські процедури внутрішнього та зовнішнього ха- } \\
\text { рактеру, пов'язані з передачею досвіду і знань }\end{array}$ \\
\hline & $\begin{array}{c}\text { Професійна } \\
\text { перепідготовка }\end{array}$ & $\begin{array}{l}\text { Отримання нової професії або кваліфікації, що є актуаль- } \\
\text { ною за сучасних умов господарювання на ринку праці }\end{array}$ \\
\hline $\begin{array}{l}\text { Зріла досвід- } \\
\text { ченість (60-- } \\
\text { до кінця } \\
\text { життя) }\end{array}$ & $\begin{array}{l}\text { «Університет } \\
\text { третього віку» }\end{array}$ & $\begin{array}{l}\text { Підтримка достатньої суспільної активності літньої людини } \\
\text { завдяки проведенню освітньо-культурних заходів }\end{array}$ \\
\hline
\end{tabular}

Складено автором на основі джерел [9-22]. 
Крім виокремлених новітніх інструментів генерації та трансформації нових знань і навичок найбільш дієвими й ефективними, незалежно від віку людини, виступають процеси самонавчання та саморозвитку [8, с. 29]. При цьому, враховуючи практично необмежені потенційні можливості людського мозку, особистість за наявності високої мотивації та внутрішньої потреби може досягти значних результатів у обраному напрямі самостійного опанування матеріалу або певних практичних навичок.

Саме тому саморозвиток має стати невід'ємною складовою знаннєвого прогресу регіону, для активізації якої мають створюватися спеціальні заходи та програми, спрямовані на підвищення суспільної позиції особистості, визначення іiі власного місця у регіональному соціумі, пропаганди корисного впливу новітніх знань на потенційні можливості підвищення якості і рівня життя людини.

Досягнення стійких тенденцій розвитку ринку праці на рівні регіону є досить складним і тривалим процесом, який вимагає комплексних підходів до управління знаннями людини протягом усього іiі життя. При цьому акценти такого управління мають змінюватися та трансформуватися зі збільшенням віку людини [9, с. 28]. Так, у дитинстві основний аспект має бути зробленим на поступовому розкритті у дитини талантів і унікальних здібностей, закладення фундаменту ii майбутнього формування як творчої особистості. Юність визначається різноманітними процедурами нагромадження тих базових знань, які будуть закладеними як основа у процеси успішного здобуття людиною тієї професії або спеціальності, яку вона свідомо обрала.

На етапі зрілості найбільшої цінності набувають інструменти отримання, закріплення та підвищення рівня професійних знань і навичок, які дозволяють побудувати успішну кар'єру та досягти гідного рівня життя. Мудрість має супроводжуватися процесами інтенсивної передачі людиною нагромаджених протягом професійного життя знань молодим працівникам, систематизацією й узагальненням здобутого досвіду у професійних каталогах, збірниках, статтях, альбомах тощо. Останній етап життєвого циклу людини має бути присвяченим забезпеченню на максимально довший період іiі фізичної, розумової та суспільної активності.

Існує велика кількість інструментів, що можуть бути використаними батьками та викладачами у дитинстві з метою активізації розумової діяльності та виявлення талантів, усебічного розвитку дитини, виховання іiі порядною та чесною людиною, відповідальним громадянином. Важливу роль при цьому відіграють методики розвитку у дитини фантазії, цікавості й уявлення (ТРВ3, ментальна арифметика, мнемоніка тощо), що лежать у основі загального інтелектуального розвитку особистості та сприяють формуванню власного креативного бачення ситуації, уміння конструктивної критики та прогнозування сценаріїв перебігу подій [23]. Досить важливо за сучасних темпів інформатизації та глобального оцифровування даних, зберегти внутрішню потребу дитини у відкритому спілкуванні та розвинути у неї почуття турботи, співпереживання, уміння контролювати й управляти власними емоціями та бути врівноваженою, не боятися змін, що допомагають досягти такі інструменти, як «Емоційний компас» або спеціальні вправи EQ-фітнесу. Додаткове використання таких традиційних інструментів, як малювання, музика, мовна та фізична підготовка доповнюють комплексний розвиток дитини, забезпечують iї самостійність, надають навички успішних соціальних комунікацій і формують базу для вибору нею власного шляху у подальшому професійному становленні.

Розвиток дитини має носити цілеспрямований характер і орієнтуватися на певний вектор руху, що відповідає професійному вибору, здійсненому нею, та сприяти максимізації віддачі від вкладених інвестицій. Вибір професії є досить складним питанням, оскільки залежить від багатьох чинників - психоемоційної, фізичної, розумової та характерологічної складових особистості, наявності талантів, схильностей і вмінь, що може бути визначено за допомогою наукових олімпіад, конкурсів і турнірів. Значний вплив на вибір людиною майбутньої спеціальності також має іiі безпосереднє оточення, наявна на момент дорослішання дитини шкала соціального престижу професій і результативність профорієнтаційної діяльності ЗВО (наукові пікніки, дні відкритих дверей) і суб'єктів господарювання регіону (форуми роботодавців, ярмарки вакансій, центри кар'єри). При цьому ступінь закріплення знань за обраною професією й успішність ії покрокового опанування залежать від прогресивності тих інструментів, що для цього було використано. Спектр зазначених інструментів $€$ досить широким і охоплює можливість отримання нових знань, досвіду та практичних навичок як у автономному відносно людини режимі (івент-платформи та автоматизовані платформи бізнес-освіти), так і у форматі спеціалізованих об’єднань різних учасників ринкових відносин регіону (освітньо-наукові та соціальні кластери, технологічні й логістичні парки, бізнес-інкубатори тощо).

В основі однієї з ключових проблем сучасного українського регіонального ринку праці, а саме розбалансованості попиту та пропозиції робочої сили, лежить невідповідність знань та умінь, отриманих випускниками навчальних закладів і їх спеціальностей виробничим потребам роботодавців. Такий розрив відбувся переважно через непродуктивне та неприродне зміщення інтересів вищої школи, соціуму та бізнес-середовища. У результаті сучасний випускник має такі основні психоемоційні характеристики, як амбіційність, ініціативність, активність i цілеспрямованість, проте не є підготовленим до реалій професійного життя та здебільшого відчуває особистісну невизначеність. При цьому, як зазна- 
чено у дослідженні «Випускники українських ЗВО очима роботодавців», серйозною перешкодою у професійній діяльності стає відсутність (або недостатній рівень володіння) навичок міжособистісного спілкування таких, як «комунікабельність, уміння презентувати, вести переговори, емоційний контроль» [24]. До того ж значною проблемою на шляху до успішного працевлаштування за фахом випускників, незалежно від рівня і напряму їхньої теоретичної підготовки, є відірваність набутих ними під час навчання знань від реальних умов практики, непідготовленість до роботи у реальному бізнесі та нерозуміння законів функціонування сучасного бізнес-середовища.

Подолати негативну тенденцію, що склалася можливо завдяки створенню освітньо-наукових кластерів і бізнес-інкубаторів, основним призначенням яких є збалансування інтересів, можливостей i перспектив функціонування та розвитку бізнесу, науки, освіти та влади, завдяки чому фахова підготовка випускників має набути осмисленості, раціональності, практичної спрямованості та змістовної наповненості. Окреслені інструменти дозволяють орієнтувати студента протягом навчання у ЗВО до конкретних вимог роботодавця, що створює підгрунтя для управління процесом придбання професійних знань і навичок, вербальну та документальну систематизацію яких доцільно відобразити у його резюме або портфоліо.

Молода людина вступає до навчального закладу з однією метою - набути гарантовану можливість працевлаштуватися за фахом та стати конкурентоздатною на ринку праці. Тобто під час навчання вона має отримати такий обсяг спеціальних знань і практичних навичок, а також такий рівень диплома, яких має бути достатньо, щоб знайти роботу, що відповідає іiї обгрунтованим очікуванням. Водночас успішність пошуку роботи залежить від багатьох чинників, одним 3 яких слід вважати наявність у фахівця практичного досвіду роботи за фахом. При цьому безпосередній пошук постійної або тимчасової роботи молода людина за сучасних складних фінансово-економічних умов у країні починає вже 3 третього курсу навчання, що дозволяє до моменту його закінчення мати не лише практичний досвід, а й сформувати власне уявлення про бажаний рівень посади, обсяг посадових обов'язків, умови праці та рейтинг роботодавця.

Здебільшого роботодавці віддають перевагу найбільш успішним випускникам ЗВО і під час працевлаштування ретельно оцінюють рівень професійних знань, отриманих молодою людиною під час навчання. Деякі з них орієнтуються під час прийому на роботу саме на молодих фахівців через економію грошових коштів на оплату їхньої праці. При цьому певна частина роботодавців обирає випускників як фахівців із твердими теоретичними знаннями, вважаючи, що практичний досвід краще отримувати вже безпосередньо на робочому місці. Тобто існує диференціація потреб і вимог роботодавців до претендента на вакантне робоче місце і так само різняться й очікування молодих людей, які шукають роботу.

Стандартним документом, який регламентовано, концентровано та з формального боку відображає нагромаджений рівень професійних знань, компетентність і набутий молодою людиною практичний досвід $\epsilon$ резюме. Водночас за умов сучасного значного перевищення пропозиції молодих фахівців на ринку праці над реальним попитом на них виникає необхідність відрізнити себе з безлічі претендентів, розкрити свої здібності та таланти, які були проявлені у студентські роки, продемонструвати набуті навички, накопичені знання з погляду їхнього фактичного застосування у практичній діяльності, чого резюме не дозволяє зробити. Тому виникає потреба у підвищенні ефективності методів розвитку кар'єри випускників 3ВО, дієвим інструментом серед яких має стати «портфоліо студента».

Портфоліо (від італ. portfolio - папка з документами) дозволяє вірно розставити життєві пріоритети та продемонструвати практичні навички та професійні компетентності, що було отримано під час навчання [16]. При цьому портфоліо одночасно виступає інструментом управління знаннями студента, тому що забезпечує концентрацію уваги, зусиль щодо здобуття необхідних компетенцій у процесі навчання для подальшого їхнього використання під час пошуку роботи та працевлаштування, що сприяє ефективному використанню усього періоду навчання й орієнтує молоду людину на обгрунтовану постановку та цілеспрямоване досягнення стратегічних цілей життя людини-професіонала.

Ринкові умови господарювання вимагають створення та постійного оновлення конкурентних переваг, в основі яких мають лежати запаси новітніх знань, навичок і провідний практичний професійний досвід персоналу. Їхнє використання у виробничій діяльності сприяє підвищенню продуктивності праці, розробці нововведень, зростанню ринкової вартості підприємства. Тому суб'єкти господарювання використовують технології управління знаннями, засновані на комплексі стандартних і нових підходів до підготовки фахівців і перетворення їх на професіоналів [25, с. 147]. При цьому призначенням кожного зовнішнього і внутрішнього інструменту кадрового менеджменту (табл. 2) $є$ певна спрямованість на конкретний механізм створення, передачі, поширення, закріплення та використання системних і практичних знань, прискорення швидкості їхнього обігу [17]. Передача знань передбачає оприлюднення фактів, стимулювання працівників до використання нових підходів і методів, розвиток здібностей і талантів, необхідних для ефективного застосування знань у конкретному економічному, діловому, інституційному, культурному чи організаційному середовищах [26]. У результаті отримані знання будуть сприяти підвищенню особистісної ефектив- 
ності працівника, його перспективному розвитку та неперервному процесу нагромадження ним додаткової доданої вартості, що є основою знаннєвого зростання регіону на шляху формування Е3.

Не існує єдиного ефективного набору інструментів забезпечення кадрових потреб, який би безумовно підходив усім без винятку суб’ єктам господарювання і тому кожен із них самостійно здійс- нює вибір методів управління персоналом, виходячи із наявної ситуації на ринку праці, економічного стану регіону, потенційних можливостей, ресурсів і стратегічних цілей. При цьому основним завданням менеджерів із персоналу суб'єктів господарювання має стати досягнення ефективності управління через оптимізацію витрат без втрати якості.

\section{Роль внутрішніх інструментів кадрового менеджменту для активізації знаннєвого розвитку}

Таблиияя 2 економічно активного населення регіону

\begin{tabular}{|c|c|c|}
\hline $\begin{array}{l}\text { Інстру- } \\
\text { мент }\end{array}$ & $\begin{array}{l}\text { Види знань, які формуються, } \\
\text { розповсюджуються, } \\
\text { використовуються }\end{array}$ & $\begin{array}{c}\text { Особливості використання професійних знань людини, } \\
\text { переваги використання інструменту }\end{array}$ \\
\hline 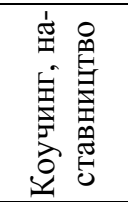 & $\begin{array}{l}\text { Практичні, понятійні, особистісні } \\
\text { та неявні знання, когнітивні знання } \\
\text { (знати що?), знання як набір спеціа- } \\
\text { льних умінь або здібностей зробити } \\
\text { що-небудь (знати як?) }\end{array}$ & $\begin{array}{l}\text { Індивідуальне або групове навчання, при якому фахівець до- } \\
\text { помагає персоналу різними методами розв’язувати висунуті } \\
\text { завдання при постійному контролі результату. Передача } \\
\text { знань, розвиток навичок і професійного досвіду, підвищення } \\
\text { продуктивності праці }\end{array}$ \\
\hline 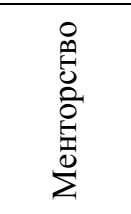 & $\begin{array}{l}\text { Практичні, понятійні, особистісні, } \\
\text { явні та неявні знання, когнітивні } \\
\text { знання (знати що?), знання як набір } \\
\text { спеціальних умінь або здібностей } \\
\text { зробити що-небудь (знати як?) }\end{array}$ & $\begin{array}{l}\text { Передача знань і практичних навичок від досвідченого пра- } \\
\text { цівника; навчання власним прикладом і шляхом моделювання } \\
\text { можливих варіантів розвитку подій та обгрунтованого вибору } \\
\text { управлінських дій у кожному випадку; розкриття талантів мо- } \\
\text { лодих працівників }\end{array}$ \\
\hline 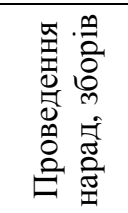 & $\begin{array}{l}\text { Неявні знання, розвинені навички, } \\
\text { знання як набір спеціальних умінь } \\
\text { або здібностей зробити що-небудь } \\
\text { (знати як?), системне розуміння } \\
\text { (знати чому?) }\end{array}$ & $\begin{array}{l}\text { Передача й обмін неявними знаннями; колективне розв’я- } \\
\text { зання виробничих і управлінських проблем, що дозволяє } \\
\text { більш інтенсивно генерувати нове колективне знання; синер- } \\
\text { гетичний ефект від заходів }\end{array}$ \\
\hline 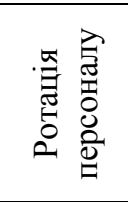 & $\begin{array}{l}\text { Процедурні та неявні знання, роз- } \\
\text { винені навички, знання як набір } \\
\text { спеціальних умінь або здібностей } \\
\text { зробити що-небудь (знати як?), си- } \\
\text { стемне розуміння (знати чому?) }\end{array}$ & $\begin{array}{l}\text { Переміщення фахівця з однієї ділянки роботи до іншої, що } \\
\text { сприяє розширенню компетентності фахівця; детальне зна- } \\
\text { йомство з іншими напрямами роботи, отримання додаткових } \\
\text { професійних знань і навичок, набуття полівалентної кваліфі- } \\
\text { кації }\end{array}$ \\
\hline
\end{tabular}

Складено автором на основі джерел [1; 17, с. 147; 26].

За умови встановлення невикористаного потенціалу працівника до опанування іншим видом діяльності або професією та наявності у нього бажання до змін може бути використаним такий інструмент ефективного кадрового менеджменту, як ротація персоналу. Саме під час внутрішньої ротації фахівці набувають полівалентної кваліфікації, яка лежить в основі забезпечення конкурентоспроможності не лише самого професіонала, а й бізнесу загалом, розвитку галузі та регіону.

Підвищити кадровий потенціал і пришвидшити нагромадження людського капіталу можливо не лише за рахунок проведення внутрішніх процедур розвитку персоналу, а й завдяки використанню зовнішніх по відношенню до суб'єкта господарювання джерел залучення претендентів на вакантні робочі місця та посади. Так, якщо кадрова стратегія спрямована на пошук і прийняття молодих, талановитих i амбітних працівників, які готові до швидкого засвоєння великих обсягів інформації та опанування методів її конструктивної обробки, проте не мають власного професійного досвіду, то може бути використаним такий інструмент кадрового менеджменту, як прелімінаринг (від лат. pre - до й limen межа) [1]. При цьому, виходячи 3 того, що найбільш високий рівень інноваційної активності людини спостерігається саме у молодому віці, інвестиції у їі професійний розвиток мають принести найвищу окупність і на найдовший термін [26]. Водночас роботодавець має чітко розуміти, що обрання зазначеної стратегії буде супроводжуватися достатнім ризиком, оскільки через високий рівень мобільності та прагнення до покращення умов життя молода людина через деякий час у результаті зростання іiі вартості на ринку праці завдяки професійному розвитку та нагромадженню достатнього обсягу фахових знань може прийняти кращу пропозицію щодо працевлаштування від конкурентів, що не дозволить окупити інвестиції у людський капітал.

Для зростання якості результатів пошуку та відбору цінного працівника фахівцям необхідно використовувати багатоступеневі технології, що 
передбачають послідовне застосування взаємодоповнюючих інструментів кадрового менеджменту, бо комплексність дозволить досягти очікуваних результатів із найменшими втратами коштів і часу, і тільки в цьому випадку недоліки одних методів будуть нівелюватися за рахунок переваг інших. Отже, комплексне використання інструментів кадрового менеджменту буде сприяти підвищенню ефективності функціонування регіонального ринку праці, оскільки створюються більш сприятливі умови праці, впроваджується гнучка система оплати праці, забезпечується підтримка привабливого бренда роботодавця. При цьому результатом є високий професіоналізм, талановитість, креативність персоналу, що є запорукою інноваційного розвитку та забезпечує конкурентні переваги людині, суб’єкту господарювання та регіону.

Водночас слід також зазначити, що чим старшим є вік людини, до якої застосовуються інструменти кадрового менеджменту, тим більшій трансформації мають підлягати мета та конкретні процедури реалізації методу. Так, якщо у молодому віці акцент під час використання кадрових інструментів має робитися на всебічному розвитку та професійному становленні молодого фахівця, то у старшому віці перевага має віддаватися процедурам передачі нагромадженого досвіду новому поколінню фахівців. Подальше життя людини має бути пов'язане 3 підтримкою достатнього рівня суспільної активності завдяки проведенню різного роду професійноспрямованих освітньо-культурних заходів, проєктів і програм, спектр яких у великих містах України вже сьогодні є досить широким.

Проведене дослідження дозволило дійти висновку, що використання будь-якого інструменту знаннєвого розвитку протягом життя людини супроводжується різними процесами, у яких беруть участь знання, що формує конкурентні переваги людини на ринку праці та поступово сприяє нагромадженню обсягу іiі людського капіталу. Водночас спостерігається різна інтенсивність зазначених процесів на тих чи інших етапах життєвого циклу людини, що вимагає врахування окресленої обставини під час створення регіональних програм розвитку (див. рисунок).

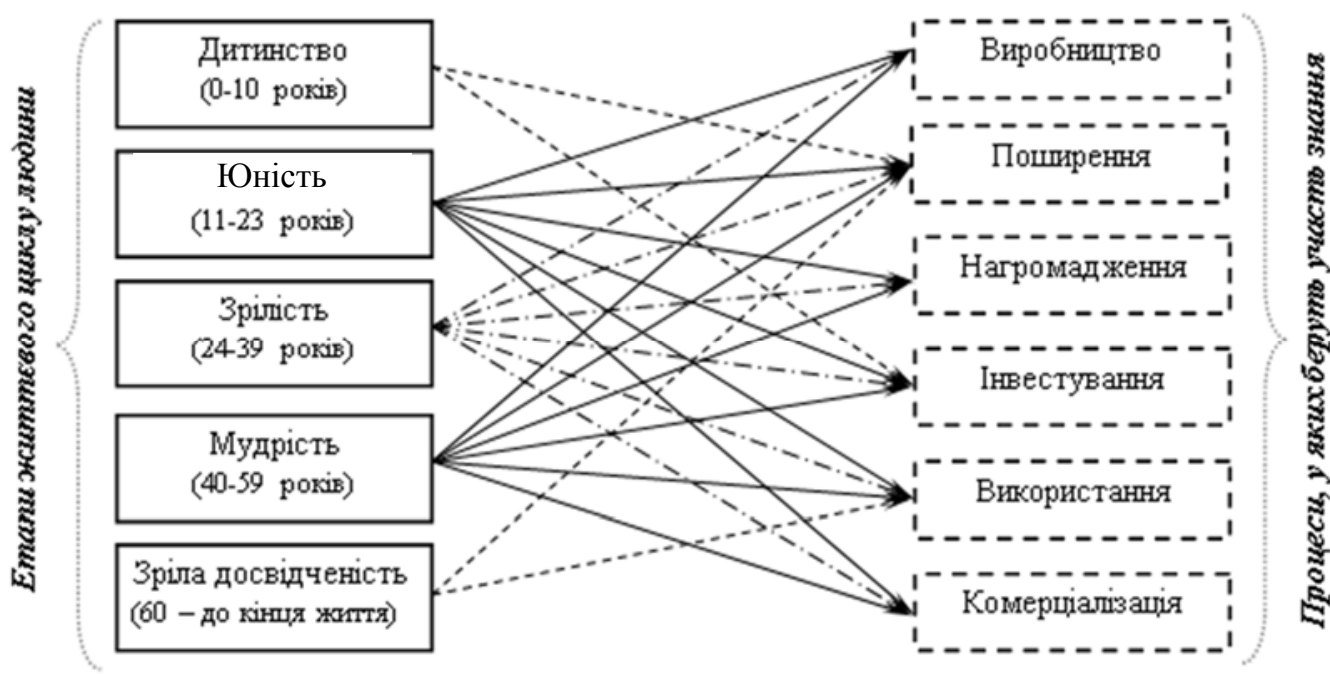

\section{Рисунок. Прояв процесів, у яких беруть участь знання на різних етапах життсвого циклу людини}

Складено автором.

Висновки. Отже, протягом життя людини спостерігаються різні процеси, у яких беруть участь знання. Так, виробництво нових знань є результатом творчої інноваційної діяльності людини, яке у середньому здійснюється у період 11-60 років. При цьому в основі активізації створення нового знання мають лежати певні внутрішні та зовнішні стимули, що спонукають людину до участі у розробці ідей i новацій. Процес поширення знань супроводжує людину протягом усього іiі життя і від того, наскільки активно i, головне, результативно він здійснюватиметься, будуть залежати успішність їі професійної сфери, кар'єрне зростання, морально-психо- логічний стан та досягнутий матеріальний добробут.

Нагромадження знань здійснюється людиною у iii найбільш продуктивному віці та базується на систематизації, зберіганні та структуруванні корисної інформації, даних і фактів із метою їх легкого застосування на практиці тоді, коли у цьому виникне необхідність. Інвестування у набуття нових знань відбувається від самого народження дитини та триває до моменту фізіологічної старості людини, коли такі процеси також продовжують здійснюватися, проте меншими обсягами та переважно носять характер хобі. 
Процес використання знань розпочинається 3 отроцтва людини та триває все ії життя, що виступає однією з базових умов життєдіяльності та професійного становлення особистості. I кульмінацією процесів знаннєвого розвитку людини виступає комерціалізація знань, яка полягає у втіленні новітніх знань у інновації з отриманням відповідних видів ефектів для самої людини та суспільства загалом і відбувається в середньому з етапу отроцтва і до моменту іiі старості. Забезпечення достатньої якості здійснення кожного з шести процесів, у яких беруть участь знання при інших рівних умовах має стати запорукою поступового зростання професіоналізму та майстерності людини за фахом, отримання нею гідного місця роботи, нагромадження людського капіталу та досягнення високого рівня життя.

\section{Лiтература}

1. Гаврилов Д.В., Бардасова Э.В. Инновационные технологии в кадровом менеджменте. Вестник Kaзанского технологического университета. 2013. Т. 16. №3. С. 267-270. 2. Гельманова 3.С., Бутрин А.Г., Гарт Н.А. Предпринимательский университет, в контексте взаимодействия «тройной спирали». International journal of applied and fundamental research. 2016. №7. С. 444-449. 3. Ицковиц Г. Тройная спираль. Университеты - предприятия - государство. Инновации 8 действии / пер. с англ., под ред. А.Ф. Уварова. Томск: Изд-во Томск. гос. ун-та систем упр. и радиоэлектроники, 2010. 238 с. 4. Ковалев М.М., Ван Син Китай строит экономику знаний: монография. Минск: Изд. центр БГУ, 2015. 152 с. 5. Шовкалюк В.С. Кластери та інноваційний розвиток України. Створення та функціонування інноваційних кластерів. Київ, 2004. C. 3-14. 6. Захарова О.В. Закономірності управління знаннями на рівні підприємства як інструмент досягнення країною стану економіки знань. 3б. наук. пращь Черкаського державного технологічного ун-ту. Серія: Економічні науки. Черкаси, 2017. №43. Т. 2. С. 29-36. 7. Исаенко А.Н., Денискин С.А. Жизненный цикл человека. Мир знаний. Педагогика и психология. 2016. №4. URL: http://www.psy.piter.com/library/ ?tp=1\&rd= $1 \& \mathrm{l}=615 \& \mathrm{p}=1273$ (дата звернення: 20.11.2017). 8. Подлужна Н.О. Економіка знань: проблеми та перспективи формування в регіонах України: монографія. Харків: ФЛП Панов А.Н., 2018. 416 с. 9. Захарова О.В. Потенціал людини третього віку для суспільства. $3 б$. наук. праць Черкаського державного технологічного ун-ту. Серія: Економічні науки. Черкаси, 2018. Вип. 49. С. 26-33. 10. Батуркина О. Как победить в битве за головами? Кадровый менеджмент. 2009. №1. С.12-15. 11. Беленко П. Хедхантинг: принципы и технологии. Санкт-Петербург: Питер, 2005. 192 с. 12. Кныш И.А., Переверзев В.Ю., Прудков С.А. Портфолио студента образовательногоучреждения СПО: Методические рекомендации по структуре, технологи организации и оценке (рейтингованию) «портфеля достижений студента». Москва: Е-Медиа, 2007. 48 с. 13. Мильнер Б. Управление знаниями: Эволюция и революция в организации. Москва: ИНФРА-М, 2003. 177 с. 14. Ныязбекова К.С. Роль «Портфолио студента» и технологий альтернативного оценивания. URL: http://www.rusnauka. com/27_OINXXI_ 2011/ Pedagogica/ 5_92867.doc.htm (дата звернення: 26.10.2015). 15. Онопріснко О.В. Портфоліо як засіб контролю результатів навчання учнів на засадах компетентнісного підходу. Психолого-педагогічні проблеми сільської школи: Зб. наук. праць Уманського державного педагогічного ун-ту ім. Павла Тичини. Умань, 2010. Вип. 34. С.121-127. 16. Подлужна Н.О. Управління знаннями майбутнього фахівця на основі формування його портфоліо. $\mathrm{Ha}$ уковий вісник Ужгородського ун-ту. Серія «Економіка». Вип. 1 (38). Ужгород, 2013. С.227-231. 17. Подлужная Н.А. Применение инструментов кадрового менеджмента в управлении знаниями предприятия. Проблемы и тенденции развития инновационной экономики: международный опыт и российская практика: сб. науч. тр. по матер. 1-й Междунар. науч.практ. конф. / редкол.: Л.И. Ванчухина и др.; под общ.ред. проф. Л.И. Ванчухиной. Т. 1. Уфа: Изд-во УГНТУ, 2013. С. 146-148. 18. Пригодій А.В. Клименок І.В. Портфоліо студента як альтернативний спосіб узагальнення та представлення навчальних досягнень. URL: http://www.nbuv.gov.ua/portal/Soc_Gum/Vchdpu/ ped/2012_97 (дата звернення: 10.09.2017). 19. Романенко Ю.А. Сучасні педагогічні технології. Донецьк: ДІСО, 2010. 152 с. 20. Степко М.Ф., Клименко Б.В. Болонський процес і навчання впродовж життя: монографія. Харків: НТУ «ХПІ», 2004. 112 с. 21. Тазутдинова Э.Х. Учебный портфолио в системе подготовки студента к будущей педагогической деятельности: дис. ... канд. пед. наук: 13.00.01; Институт педагогики и психологии профессионального образования. Москва, 2010. 200 с. 22. Харрингтон Дж., Воул Ф. Совершенство управления знаниями / пер с англ. А.Л. Раскина; под ред. А.Б. Болдина. Москва: РИА «Стандарты и качество», 2008. 272 с. 23. Goodwin T. Forget coding, we need to teach our kids dream. World Economic Forum. 2017. URL: https://www.weforum.org/agenda/2017/04/ forget-coding-we-need-to-teach-our-kids-how-to-dream/w to (дата звернення: 20.02.2018). 24. Випускники українських ВНЗ очима роботодавців. СКМ. 2012. URL: https://www.yourcompass.org/docs/Employees \%20 on\%20University_Graduates. pdf (дата звернення: 16.10.2017). 25. Подлужна Н.О. Методологічні особливості оцінки економіки знань. Зб. наук. пр. Черкаського державного технологічного університету. Серія: Економічні науки. 2016. №42. С. 41-50. 26. Podluzhna N.O. The role of economy of knowledge in the postindustrial environment. International Journal of New Economics and Social Sciences. Warszawa. 2017. №1 (5). pp. 130-142.

\section{References}

1. Gavrilov D.V., Bardasova E.V. (2013). Innovative technologies in personnel management. Bulletin of Kazan Technological University, Vol. 16, №3, pp. 267-270 449 [in Russian].

2. Gelmanova Z.S., Butrin A.G., Gart N.A. (2016). Entrepreneurial University, in the context of the interaction of the "triple helix". International journal of applied and fundamental research, 7, pp. 444-449 [in Russian]. 
3. Itskowitz G. (2010). Triple Helix. Universities enterprises - state. Innovation in action. Trans. from English. Tomsk. Tomsk Publishing House. state University of Control Systems and radio electronics [in Russian].

4. Kovalev M.M., Wang Xing. (2015). China is building a knowledge economy. Minsk, Publishing House BSU Center [in Russian].

5. Shovkaliuk V.S. (2004). Klastery ta innovatsiinyi rozvytok Ukrainy [Clusters and innovative development of Ukraine]. Stvorennia ta funktsionuvannia innovatsiinykh klasteriv - Creation and functioning of innovation clusters, pp. 3-14. Kyiv [in Ukrainian].

6. Zakharova O.V. (2017). Zakonomirnosti upravlinnia znanniamy na rivni pidpryiemstva yak instrument dosiahnennia krainoiu stanu ekonomiky znan [Regularities of knowledge management at the enterprise level as a tool for the country to achieve the state of the knowledge economy]. Zb. nauk. prats Cherkaskoho derzhavnoho tekhnolohichnoho un-tu. Seriia: Ekonomichni nauky - Coll. Science. Proceedings of Cherkasy State Technological University. Series: Economic Sciences, 43, Vol. 2, pp. 29-36 [in Ukrainian].

7. Isayenko A.N., Deniskin S.A. (2016). Zhiznennyy tsikl cheloveka [The life cycle of a person]. Mir znaniy. Pedagogika i psikhologiya - The world of knowledge. Pedagogy and psychology, 4. Retrieved from http://www.psy. piter.com/library/?tp=1\&rd=1\&l=615\&p=1273 [in Russian].

8. Podluzhna N.O. (2018). Ekonomika znan: problemy ta perspektyvy formuvannia $\mathrm{v}$ rehionakh Ukrainy [Economy knowledge: problems and perspectives of formulations in the regions of Ukraine]. Kharkiv, FLP Panov A.N. [in Ukrainian].

9. Zakharova O.V. (2018). Potentsial liudyny tretoho viku dlia suspilstva [The potential of the third age for society]. Zb. nauk. prats Cherkaskoho derzhavnoho tekhnolohichnoho un-tu. Seriia: Ekonomichni nauky - Coll. Science. Proceedings of Cherkasy State Technological University. Series: Economic Sciences, Issue 49, pp. 26-33 [in Ukrainian].

10. Baturkina O. (2009). Kak pobedit' v bitve za golovami? [How to win the battle behind the head?]. Kadrovyy menedzhment - HR management, 1, pp. 12-15 [in Russian].

11. Belenko P. (2005). Khedkhanting: printsipy i tekhnologii [Headhunting: principles and technologies]. St. Petersburg, Piter [in Russian].

12. Knysh I.A., Pereverzev V.YU., Prudkov S.A. (2007). Portfolio studenta obrazovatel'nogo uchrezhdeniya SPO: Metodicheskiye rekomendatsii po strukture, tekhnologi organizatsii i otsenke (reytingovaniyu) «portfelya dostizheniy studenta» [Portfolio of a student of an educational institution of secondary vocational education: Methodological recommendations on the structure, technology of organization and evaluation (rating) of the "portfolio of student achievements"]. Moscow, E-Media [in Russian].

13. Mil'ner B. (2003). Upravleniye znaniyami: Evolyutsiya i revolyutsiya v organizatsii [Knowledge Management: Evolution and Revolution in Organizations]. Moscow, INFRA-M [in Russian].

14. Nyyazbekova K.S. Rol' «Portfolio studenta» i tekhnologiy al'ternativnogo otsenivaniya [Role of Student
Portfolio and Alternative Assessment Technologies]. (n.d.). Retrieved from http://www.rusnauka.com/27_OI NXXI_2011/Pedagogica/5_92867.doc.htm [in Russian].

15. Onopriienko O.V. (2010). Portfolio yak zasib kontroliu rezultativ navchannia uchniv na zasadakh kompetentnisnoho pidkhodu [Portfolio as a means of monitoring student learning outcomes on the basis of a competency-based approach]. Psykholoho-pedahohichni problemy silskoi shkoly - Psychological and pedagogical problems of rural schools, Issue 34, pp. 121-127 [in Ukrainian].

16. Podluzhna N.O. (2013). Upravlinnia znanniamy maibutnoho fakhivtsia na osnovi formuvannia yoho portfolio [Knowledge management of the future specialist based on the formation of his portfolio]. Naukovyi visnyk Uzhhorodskoho un-tu. Seriia «Ekonomika» - Scientific Bulletin of Uzhhorod University. Economics series, Issue 1 (38), pp. 227-231 [in Ukrainian].

17. Podluzhnaya N.A. (2013). Primeneniye instrumentov kadrovogo menedzhmenta $\mathrm{v}$ upravlenii znaniyami predpriyatiya [The use of personnel management tools in enterprise knowledge management]. Problemy i tendentsii razvitiya innovatsionnoy ekonomiki: mezhdunarodnyy opyt i rossiyskaya praktika - Problems and trends in the development of an innovative economy: international experience and Russian practice, Vol. 1, pp. 146-148. Proceedings of the 1st International scientific-practical conference. Ufa, Publishing House of Ural State Technical University [in Russian].

18. Pryhodii A.V. Klymenok I.V. Portfolio studenta yak alternatyvnyi sposib uzahalnennia ta predstavlennia navchalnykh dosiahnen [Student portfolio as an alternative way of generalizing and presenting academic achievements]. (n.d.). Retrieved from http://www.nbuv.gov.ua/ portal/Soc_Gum/Vchdpu/ped/2012_97 [in Ukrainian].

19. Romanenko Yu.A. (2010). Suchasni pedahohichni tekhnolohii [Modern pedagogical technologies]. Donetsk, DISO [in Ukrainian].

20. Stepko M.F., Klymenko B.V. (2004). Bolonskyi protses i navchannia vprodovzh zhyttia [Bologna process and lifelong learning]. Kharkiv, NTU «KhPI» [in Ukrainian].

21. Tazutdinova E.Kh. (2010). Uchebnyy portfolio v sisteme podgotovki studenta $\mathrm{k}$ budushchey pedagogicheskoy deyatel'nosti [The educational portfolio in the system of preparing a student for future pedagogical activity]. Candidate's thesis. Moscow, Institute of Pedagogy and Psychology of Professional Education [in Russian].

22. Harrington J., Voul F. (2008). Perfection of knowledge management. Transl. From English by A.L. Ruskin; Moscow, RIA "Standards and Quality" [in Russian].

23. Goodwin T. (2017). Forget coding, we need to teach our kids dream. World Economic Forum. Retrieved from https://www.weforum.org/agenda/2017/04/ forgetcoding-we-need-to-teach-our-kids-how-to-dream/wto.

24. Vypusknyky ukrainskykh VNZ ochyma robotodavtsiv [Graduates of Ukrainian universities through the eyes of employers]. (2012). SCM. Retrieved from https: //www.yourcompass.org/docs/Employees \%20 on\%20Uni versity_Graduates [in Ukrainian].

25. Podluzhna N.O. (2016). Metodolohichni osoblyvosti otsinky ekonomiky znan [Methodological features of 
knowledge economy assessment]. Zb. nauk. pr. Cherkaskoho derzhavnoho tekhnolohichnoho universytetu. Seriia: Ekonomichni nauky - Coll. Science. Cherkasy State Technological University. Series: Economic Sciences, 42, pp. 41-50 [in Ukrainian].

26. Podluzhna N.O. (2017). The role of economy of knowledge in the postindustrial environment. International Journal of New Economics and Social Sciences, №1 (5), pp. 130-142.

Подлужна Н. О. Регулювання регіонального ринку праці на основі використання методів навчання населення протягом усього життя

У статті визначено методи нагромадження знань людиною протягом іiі життя та інструментів кадрового менеджменту суб'єктами господарювання, які підвищують ефективність функціонування регіонального ринку праці. Досліджено й узагальнено підходи, що використовуються у науковому середовищі до розмежування стадій життєвого циклу людини, що дозволило обрати п’ять загальноприйнятих етапів, кожен 3 яких $\epsilon$ чітко регламентованим за віковими критеріями, серед яких є дитинство, юність, зрілість, мудрість, зріла досвідченість. Визначено, що виробництво нових знань $є$ результатом творчої інноваційної діяльності людини, яке у середньому здійснюється у період 1160 років. Систематизовано інструменти знаннєвого розвитку людини протягом іiї життя та розкрито їхне змістовне наповнення, використання яких дозволить підвищити якість людського капіталу на регіональному ринку праці. Визначено роль внутрішніх інструментів кадрового менеджменту для активізації знаннєвого розвитку економічно активного населення регіону, до яких віднесено коучинг, наставництво, менторство, проведення нарад, ротація персоналу, прелімінаринг. Обгрунтовано, що використання будь-якого інструменту знаннєвого розвитку протягом життя людини супроводжується різними процесами, у яких беруть участь знання, що формує конкурентні переваги людини на ринку праці та поступово сприяє нагромадженню обсягу її людського капіталу.

Ключові слова: ринок праці, знаннєвий розвиток, регіон, кадровий менеджмент, населення, навчання протягом життя, стадії життєвого циклу людину.

Podluzhna N. Regulation of the Regional Labor Market Based on the Use of the Methods of Education of the Population for the Whole Life

The article defines the methods of accumulating knowledge by a person during his or her life and the tools of personnel management by business entities that increase the efficiency of the functioning of the regional labor market. The approaches used in the scientific environment to distinguish between stages of the human life cycle were examined and generalized, which made it possible to choose five conventional stages, each of which is clearly regulated by age criteria, including childhood, youth, maturity, wisdom, mature experience. It was determined that the production of new knowledge is the result of creative innovative human activity, which is carried out on average in the period of 11-60 years. The tools of knowledge development of a person during his or her life were systematized and their meaningful content was disclosed, the use of which will improve the quality of human capital in the regional labor market. The role of the internal tools of personnel management for enhancing the knowledge upgrowth of the economically active population of the region, which includes coaching, tutorship, mentoring, meetings, staff rotation, and preliminarity, was determined. It was proved that the use of any tool of knowledge development throughout a person's life is accompanied by various processes in which knowledge takes part, forms a person's competitive advantages in the labor market and gradually contributes to the accumulation of their human capital.

Keywords: labor market, knowledge development, region, personnel management, population, lifelong learning, stages of a person's life cycle labor market, knowledge development, region, personnel management, population, lifelong learning, stages of a person's life cycle.

Подлужная Н. А. Регулирование регионального рынка труда на основе использования методов обучения населения на протяжении всей жизни

В статье определены методы накопления знаний человеком в течение его жизни и инструменты кадрового менеджмента субъектами хозяйствования, которые повышают эффективность функционирования регионального рынка труда. Исследованы и обобщены подходы, используемые в научной среде для разграничения стадий жизненного цикла человека, что позволило выбрать пять общепринятых этапов, каждый из которых четко регламентируется по возрастным критериям, среди которых детство, юность, зрелость, мудрость, зрелая опытность. Определено, что производство новых знаний является результатом творческой инновационной деятельности человека, которое в среднем осуществляется в период 11-60 лет. Систематизированы инструменты знаниевого развития человека в течение его жизни и раскрыто их содержательное наполнение, использование которых позволит повысить качество человеческого капитала на региональном рынке труда. Определена роль внутренних инструментов кадрового менеджмента для активизации знаниевого развития экономически активного населения региона, к которым отнесены коучинг, наставничество, менторство, проведения совещаний, ротация персонала, прелиминаринг. Обосновано, что использование любого инструмента знаниевого развития на протяжении жизни человека сопровождается различными процессами, в которых принимают участие знания, формирует конкурентные преимущества человека на рынке труда и постепенно способствует накоплению объема ее человеческого капитала.

Ключевые слова: рынок труда, знаниевое развитие, регион, кадровый менеджмент, население, обучение в течение жизни, стадии жизненного цикла человека.

Стаття надійшла до редакції 22.01.2020

Прийнято до друку 20.02.2020 